\title{
The Pulse of Asia 2021 Seoul
}

July 2-3, 2021, Seoul, Republic of Korea

\section{Abstracts}

\section{POA 2021 \\ Pulse of Asia 2021 Seoul}

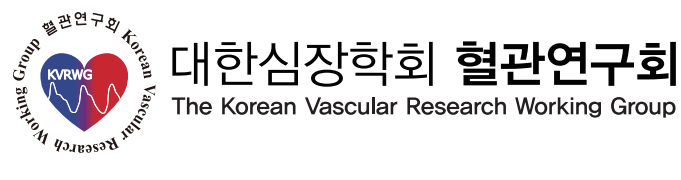

Conference Chair

Ki-Chul Sung, Seoul, Republic of Korea

Guest Editors

Jong-Won Ha, Seoul, Republic of Korea

II Suk Sohn, Seoul, Republic of Korea

Hae-Young Lee, Seoul, Republic of Korea 


\section{Conflict of Interest Statements Guest Editors}

Jong-Won Ha and II Suk Sohn have no potential conflict of interest to disclose and Hae-Young Lee received speakers' fees from Sanofi, Boehringer Ingelheim, Pfizer, MSD, Boryung, Bayer, Daiichi Sankyo, Novartis, and Astra Zeneca.

\section{S. Karger}

Medical and Scientific Publishers Basel $\cdot$ Freiburg $\cdot$ Hartford · Oxford Bangkok $\cdot$ Dubai $\cdot$ Kuala Lumpur · Melbourne $\cdot$ Mexico City

Moscow $\cdot$ New Delhi $\cdot$ Paris .

Shanghai $\cdot$ Tokyo

\section{Disclaimer}

The statements, opinions and data contained in this publication are solely those of the individual authors and contributor and not of the publisher and the editor(s). The appearance of advertisements in the journal is not a warranty, endorsement, or approval of the products or services advertised or of their effectiveness, quality or safety. The publisher and the editor(s) disclaim responsibility for any injury to persons or property resulting from any ideas, methods, instructions or products referred to in the content or advertisements.

Drug Dosage

The authors and the publisher have exerted every effort to ensure that drug selection and dosage set forth in this text are in accord with current recommendations and practice at the time of publication. However, in view of ongoing research, changes in government regulations, and the constant flow of information relating to drug therapy and drug reactions, the reader is urged to check the package insert for each drug for any change in indications and dosage and for added warnings and precautions. This is particularly important when the recommended agent is a new and/or infrequently employed drug.
All rights reserved.

No part of this publication may be translated into other languages, reproduced or utilized in any form or by any means, electronic or mechanical, including photocopying, recording microcopying, or by any information storage and retrieval system, without permission in writing from the publisher or in the case of photocopying, direct payment of a specified fee to the Copyright Clearance Center (see 'General Information').

(C) Copyright 2021 by S. Karger AG

P.O. Box, CH-4009 Basel (Switzerland)

e-ISBN 978-3-318-07006-4 


\section{The Pulse of Asia 2021 Seoul}

\section{Contents}

IV Welcome Letter

V Scientific Program

Invited Lecture Summary

2 Summary I-02-I-27

Featured Scholar Invited Lecture Summary

14 Summary Fl-01-FI-05

Oral Abstracts

17 Outstanding Abstracts $\mathrm{O}-01-\mathrm{O}-02$

18 Moderated Session O-03-O-08

e-Poster Abstracts

26 Abstracts eP-01-eP-47 


\begin{tabular}{l|l}
\hline Pulse 2021;9(suppl 1): I-VIII \\
\hline DOI: 10.1159/000517557 & $\begin{array}{l}\text { (c) 2021 S. Karger AG, Basel } \\
\text { www.karger.com/pls }\end{array}$ \\
\hline
\end{tabular}

Abstracts: The Pulse of Asia 2021 Seoul

\section{Welcome Letter}

\section{Pulse of Asia 2021 in Seoul}

Dear Friends and Colleagues,

The Pulse of Asia (POA) biennial scientific meeting entered its 12th year. We have been preparing this meeting hoping that the 12th meeting of the Pulse of Asia would be a milestone for the POA Society and scientific research on arterial properties in Asia.

Although we suspended the congress for one year wishing the COVID-19 pandemic subsided, however, the vaccination schedule is still ongoing and traveling abroad is limited in most countries. Therefore, we have decided to hold POA 2021 in a hybrid platform as our utmost concern is to keep the good health of all participants.

In this regard, we cordially invite you to attend the POA 2021 meeting, which will be held in Seoul from July 2 (Friday) to 3 (Saturday), 2021 as a format of a hybrid meeting for the first time in the history of the POA. The Korean participants will attend in-person/on-site, while the overseas participants will join the meeting online. The meeting will be organized by the Pulse of Asia Society in conjunction with the Summer Scientific Meeting of the Korean Vascular Research Working Group (KVRWG).

We would invite top scientists in the field of arterial research in Asia and other parts of the world to give lectures on various topics in clinical, basic and, population research to provide diverse scientific programs online to gratify academic passion and support of our members.

Most importantly, we welcome and also will provide support for young investigators to present their research on vessels and pulse.

We would like to ask for your active participation in POA 2021 so that it could become a prestigious meeting recognized globally with plenty of vascular knowledge.

See you in Seoul in July 2021.

\section{Organizing Committee of The Pulse of Asia 2021 Seoul}




\begin{tabular}{l|l}
\hline Pulse 2021;9(suppl 1): I-VIII \\
\hline DOI: $10.1159 / 000517557$ & $\begin{array}{l}\text { (c) 2021 S. Karger AG, Basel } \\
\text { www.karger.com/pls }\end{array}$ \\
\hline
\end{tabular}

Abstracts: The Pulse of Asia 2021 Seoul

\section{Scientific Program}

\section{Day 1 / July 2 (Fri)}

\begin{tabular}{|c|c|}
\hline 08:00-11:30 & Registration \\
\hline 11:30-12:20 & $\begin{array}{l}\text { Moderated Session } \\
\text { Chairs Sung-Kee Ryu (Korea), Hao-Min Cheng (Taiwan) }\end{array}$ \\
\hline 11:30-11:37 & $\begin{array}{l}\text { Visceral Adipose Tissue, Coronary Artery Calcification and Heart Failure: A Moderated Mediation Analysis } \\
\text { Chun-Wei Lee (Taiwan) }\end{array}$ \\
\hline 11:37-11:44 & $\begin{array}{l}\text { Ambulatory Pulse Pressure Components and Ambulatory Arterial Stiffness Index in Chinese Outpatients } \\
\text { Mingxuan Li (China) }\end{array}$ \\
\hline 11:44-11:51 & $\begin{array}{l}\text { Early and Supernormal Vascular Aging: Associations with Cognitive Dysfunction in a Community-based Healthy } \\
\text { Population Chen-Hua Lin (Taiwan) }\end{array}$ \\
\hline 11:51-11:58 & $\begin{array}{l}\text { Comparison of Vascular Characteristic Impedance Estimation in Time Domain or Frequency Domain } \\
\text { Audrey Adji (Australia) }\end{array}$ \\
\hline 11:58-12:05 & $\begin{array}{l}\text { Moderate to Severe Obstructive Sleep Apnea Is Independently Associated with Inter-arm Systolic Blood Pressure } \\
\text { Difference -Tokyo Heart Sleep Study- Kazuki Shïna (Japan) }\end{array}$ \\
\hline 12:05-12:12 & $\begin{array}{l}\text { The Cardio-ankle Vascular Index Was Associated with CHADS2 Score in Patients with Atrial Fibrillation: A Coupling } \\
\text { Registry Study Tomoyuki Kabutoya (Japan) }\end{array}$ \\
\hline 12:12-12:20 & Discussion Panels Jae-Hyeong Park (Korea), Eun Joo Cho (Korea) \\
\hline 12:20-13:20 & $\begin{array}{l}\text { Satellite Symposium I (산학협력세션 I) } \\
\text { Chairs Dong-Soo Kim (Korea), Seung-Jae Joo (Korea) }\end{array}$ \\
\hline 12:20-12:50 & $\begin{array}{l}\text { Novartis } \\
\text { The Benefits of Early Optimization for HF Patients Hae-Young Lee (Korea) }\end{array}$ \\
\hline 12:50-13:20 & $\begin{array}{l}\text { Organon } \\
\text { Is Combination Therapy Recommended for High Risk ASCVD Patients? : When and Why Combination Therapy Is } \\
\text { Needed Iksung Cho (Korea) }\end{array}$ \\
\hline 13:20-13:30 & Opening \\
\hline \multirow[t]{2}{*}{ 13:30-14:00 } & $\begin{array}{l}\text { Opening Lecture } \\
\text { Chair Jeong Bae Park (Korea) }\end{array}$ \\
\hline & Heart Failure with Preserved Ejection Fraction, Diastolic Dysfunction and Arterial Stiffening Jong-Won Ha (Korea) \\
\hline 14:00-15:40 & $\begin{array}{l}\text { POA Featured Scholar Invited Lecture } \\
\text { Chairs Young Moo Ro (Korea), Chen-Huan Chen (Taiwan) }\end{array}$ \\
\hline 14:00-14:18 & Basic Concepts and New Evidence of Vascular Biomarkers Alberto Avolio (Australia) \\
\hline 14:18-14:36 & Implication of 24-hour Central Blood Pressure Monitoring Jin-Ho Shin (Korea) \\
\hline 14:36-14:54 & Antihypertensive Treatment and Arterial Stiffness Jiguang Wang (China) \\
\hline 14:54-15:12 & $\begin{array}{l}\text { Central Blood Pressure and Pressure Wave Reflection in Cardiovascular Abnormalities: Do Not Put Them in Shade } \\
\text { Hirofumi Tomiyama (Japan) }\end{array}$ \\
\hline 15:12-15:30 & Association between Excess Pressure and Cognitive Function among Elderly Population Chen-Huan Chen (Taiwan) \\
\hline 15:30-15:40 & Discussion Panels Woong Chol Kang (Korea), Hae-Young Lee (Korea), Hyeon Chang Kim (Korea) \\
\hline 15:40-16:10 & Coffee Break \\
\hline 16:10-17:20 & $\begin{array}{l}\text { New Technology to Measure Blood Pressure } \\
\text { Chairs Wook Bum Pyun (Korea), Jiguang Wang (China) }\end{array}$ \\
\hline 16:10-16:25 & Need of Noninvasive, Continuous BP Monitoring in the "Digital Hypertension" Era Kazuomi Kario (Japan) \\
\hline 16:25-16:40 & $\begin{array}{l}\text { Non-invasive Continuous Arterial Blood Pressure Monitoring System Using Single Chest-worn Device } \\
\text { Hee Chan Kim (Korea) }\end{array}$ \\
\hline
\end{tabular}




\begin{tabular}{l|l}
\hline Pulse 2021;9(suppl 1): I-VIII \\
\hline DOI: 10.1159/000517557 & $\begin{array}{l}\text { (c) 2021 S. Karger AG, Basel } \\
\text { www.karger.com/pls }\end{array}$ \\
\hline
\end{tabular}

Abstracts: The Pulse of Asia 2021 Seoul

\begin{aligned} & \hline 16:40-16:55 Continuous Blood Pressure Monitoring by Tactile Sensor Jong-Mo Seo (Korea) \\
& \hline 16:55-17:10 Continuous Monitoring of Blood Pressures Using Cuffless Device: Present and Future Hao-Min Cheng (Taiwan) \\
& \hline 17:10-17:20 Discussion Panels Ju han Kim (Korea), Jeong-Hun Shin (Korea), Sang-Hyun Ihm (Korea) \\
& \hline 17:20-18:30 $\begin{array}{l}\text { Vascular Stiffness in Daily Life } \\
\text { Chairs Kee-Sik Kim (Korea), Pierre Boutouyrie (France) }\end{array} \\
&$\hline 17:20-17:35 Future of Arterial Stiffness Measurement, Clinical Applications Pierre Boutouyrie (France) \\
& \hline 17:35-17:50 Central Blood Pressure as a Predictor of Cardiovascular Risk Yan Li (China) \\
& \hline 17:50-18:05 $\begin{array}{l}\text { Prognostic Evidence on Brachial-ankle Pulse Wave Velocity: Why It Is Better than Initially Expected? } \\
\text { Masanori Munakata (Japan) }\end{array} \\
&$\hline 18:20-18:30 \begin{tabular}{l} 
Cardiorespiratory Fitness and Vascular Aging Sae Young Jae (Korea) \\
\hline 18:30-20:00 Panels Jang Young Kim (Korea), Gyu Chul Oh (Korea), Heesun Lee (Korea)
\end{tabular} \\
& \hline $\begin{array}{l}\text { Satellite Symposium II (산학협력세션 II / 후원의 밤) } \\
\text { Chairs Hae-Ok Jung (Korea) }\end{array} \\
&$\hline Approaches for the Medical Management of Resistant Hypertension \& Role of SPC /l Suk Sohn (Korea) \\
& \hline\end{aligned}

Day 2 / July 3 (Sat)

\begin{tabular}{|c|c|}
\hline 07:30-09:30 & Registration \\
\hline 08:30-09:30 & $\begin{array}{l}\text { COVID-19 and Vaccination } \\
\text { Chairs Ju han Kim (Korea), Tzung-Dau Wang (Taiwan) }\end{array}$ \\
\hline 08:30-08:45 & Cardiovascular System and COVID-19 Hae-Young Lee (Korea) \\
\hline 08:45-09:00 & Long Term Sequale on COVID-19 In-Cheol Kim (Korea) \\
\hline 09:00-09:15 & Adverse Effects on COVID-19 Vaccination: Myth or Fact? Sang Hoon Na (Korea) \\
\hline 09:15-09:30 & Discussion Panels Eui-Cheol Shin (Korea), Seong Hwan Kim (Korea) \\
\hline 09:30-10:45 & $\begin{array}{l}\text { Cutting Edge Vascular Research } \\
\text { Chairs Byung-Hee Oh (Korea), Kazuomi Kario (Japan) }\end{array}$ \\
\hline 09:30-09:50 & Effect of Physical Activity on Vascular Risk Factors Ki-Chul Sung (Korea) \\
\hline 09:50-10:10 & US Update on Arterial Stiffness Raymond Townsend (USA) \\
\hline 10:10-10:30 & Fighting Vascular Disease: Thoughts about 2022 Taiwan Hypertension Guidelines Tzung-Dau Wang (Taiwan) \\
\hline 10:30-10:45 & Discussion Panels Sungha Park (Korea), Jin-Ho Shin (Korea), Jang-ho Bae (Korea) \\
\hline 10:45-11:00 & Coffee Break \\
\hline $11: 00-12: 30$ & $\begin{array}{l}\text { Vascular Evaluation in the Future } \\
\text { Chairs Byung Su Yoo (Korea), Alberto Avolio (Australia) }\end{array}$ \\
\hline 11:00-11:15 & Nanomedicine for the Treatment of Atherosclerosis Ji-Ho Park (Korea) \\
\hline 11:15-11:30 & Quantification of Hemodynamic Parameters Using 4D Flow MRI Hojin Ha (Korea) \\
\hline 11:30-11:45 & Direct Thrombus Imaging Dong-Eog Kim (Korea) \\
\hline $11: 45-12: 00$ & Real-time Intravital Microscopy for Visualization of Microcirculation Pilhan Kim (Korea) \\
\hline 12:00-12:15 & Imaging Based Diagnosis and Treatment on Lymphatic Flow Disorders Ji Hoon Shin (Korea) \\
\hline $12: 15-12: 30$ & Discussion Panels Hak-Joon Sung (Korea), Chan Joo Lee (Korea), Jin-Ok Jeong (Korea) \\
\hline
\end{tabular}




\begin{tabular}{l|l}
\hline Pulse 2021;9(suppl 1): I-VIII \\
\hline DOI: $10.1159 / 000517557$ & $\begin{array}{l}\text { (c) 2021 S. Karger AG, Basel } \\
\text { www.karger.com/pls }\end{array}$ \\
\hline
\end{tabular}

Abstracts: The Pulse of Asia 2021 Seoul

\begin{tabular}{|c|c|}
\hline 12:30-13:30 & $\begin{array}{l}\text { Satellite Symposium III (산학협력세션 III) } \\
\text { Chairs Sang-Hyun Ihm (Korea), Jang Young Kim (Korea) }\end{array}$ \\
\hline 12:30-13:00 & Viatris Long-term Benefit of BP, Lipid Lowering Management Weon Kim (Korea) \\
\hline 13:00-13:30 & Bristol Myers Squibb Current Perspective on NOAC Trials in Managing VTE Patients Chan Joo Lee (Korea) \\
\hline 13:30-15:00 & $\begin{array}{l}\text { Distinguished Clinical Research Session (Clinical, Epidemiology) } \\
\text { Chairs Moo-Yong Rhee (Korea), Masanori Munakata (Japan) }\end{array}$ \\
\hline 13:30-13:45 & Aortic Stiffness and Subclinical Left Ventricular Dysfunction Chi Young Shim (Korea) \\
\hline 13:45-14:00 & $\begin{array}{l}\text { Carotid-femoral Pulse Transit Time Variability Predicted Mortality and Improved Risk Stratification in the Elderly } \\
\text { De-Wei An (China) }\end{array}$ \\
\hline 14:00-14:15 & Fatty Liver Index (FLI) and Cardiovascular Disease Jang Young Kim (Korea) \\
\hline 14:15-14:30 & A Cohort Study of Resistant Hypertension in Korea Sungha Park (Korea) \\
\hline 14:30-14:45 & Clinical Outcome in Patients with Deep Vein Thrombosis Sung-Ai Kim (Korea) \\
\hline 14:45-15:00 & Discussion Panels Dae-Hee Kim (Korea), Jaehyuk Choi (Korea), Kwang-il Kim (Korea) \\
\hline 15:00-15:30 & Coffee Break \\
\hline 15:30-16:45 & $\begin{array}{l}\text { Diabetes Mellitus: Vascular Disease (Bench to bedside) } \\
\text { Chairs Sang-Hyun Kim (Korea), Hirofumi Tomiyama (Japan) }\end{array}$ \\
\hline 15:30-15:45 & Analysis of Plasma and Fat Tissue Omics in Patients with Atherosclerosis and Diabetes Sung Hee Choi (Korea) \\
\hline 15:45-16:00 & Sox17 Deficiency Promotes Pulmonary Arterial Hypertension via HGF/c-Met Signaling In-june Kim (Korea) \\
\hline 16:00-16:15 & Cardiovascular Benefits of SGLT-2 Inhibitor Jiwon Seo (Korea) \\
\hline 16:15-16:30 & $\begin{array}{l}\text { Associations between Arterial Aging and Muscle-to-fat Ratio among Middle-aged and Older Adults: Results from the } \\
\text { Longitudinal Aging Study of Taipei Hsin-Yu Liu (Taiwan) }\end{array}$ \\
\hline 16:30-16:45 & Discussion Panels Sunki Lee (Korea), Jung-Woo Son (Korea), Soon Jun Hong (Korea) \\
\hline 16:45-17:00 & $\begin{array}{l}\text { Lifetime Achievement Award } \\
\text { Chair Ki-Chul Sung (Korea) }\end{array}$ \\
\hline 16:45-17:00 & A Journey along the Illuminating Pathways of Interdisciplinary Science Alberto Avolio (Australia) \\
\hline 17:00-17:10 & POA 2022 Kyoto at Japan \\
\hline 17:10-17:40 & $\begin{array}{l}\text { POA Award and Closing } \\
\text { Chair Ki-Chul Sung (Korea) }\end{array}$ \\
\hline
\end{tabular}


